\title{
AFFECT ANALYSIS OF CRIME NEWS IN THE JAKARTA POST AND THE JAKARTA GLOBE: A STUDY OF SYSTEMIC FUNCTIONAL LINGUISTICS
}

\author{
Dien Novita \\ Politeknik LP3I Bandung \\ dienovita988@gmail.com \\ Eva Tuckyta Sari Sujatna \\ Fakultas Ilmu Budaya Universitas Padjadjaran \\ eva.tuckyta@unpad.ac.id
}

\begin{abstract}
This study explores the affect of appraisal systems by comparing the crime news in The Jakarta Post and The Jakarta Globe. There were six texts of the crime news that were classified into the same topics. These texts were analysed using Appraisal Systems Theory (Martin \& White, 2005). The objectives of the present study are to find out the differences of the affect of crime news in The Jakarta Post and The Jakarta Globe and then to know the types of appraising items in The Jakarta Post and The Jakarta Globe. The data were analysed by using the mixed method research. The result of this research shows that The Jakarta Globe present the affect dominantly. The Jakarta Globe shows $63,8 \%$ of affect and it is dominated by the affect of dis/satisfaction. However, The Jakarta Post shows $36,2 \%$ of affect and it is dominated by the affect of in/security. In addition, the types of appraising items that occur in the affect of crime news are mental process, behavioural process, relational process, attitudinal lexis, minor clause, epithet and grammatical item.
\end{abstract}

Keywords: Appraisal system; Affect; Crime News

\begin{abstract}
Abstrak
Studi ini mengeksplorasi Affect of Appraisal System dengan membandingkan berita kriminal di The Jakarta Post dan The Jakarta Globe. Ada enam teks berita kriminal yang diklasifikasikan ke dalam topik yang sama. Teks-teks ini dianalisis menggunakan Teori Appraisal System (Martin \& White, 2005). Tujuan dari penelitian ini adalah untuk mengetahui perbedaan affect berita kriminal di The Jakarta Post dan The Jakarta Globe dan kemudian untuk mengetahui jenis-jenis appraising items di The Jakarta Post dan The Jakarta Globe. Data dianalisis dengan menggunakan metode penelitian campuran. Hasil penelitian menunjukkan bahwa The Jakarta Globe menyajikan affect secara dominan. The Jakarta Globe menunjukkan 63,8\% affect dan didominasi oleh affect of dis/satisfaction. Sementara itu, The Jakarta Post menunjukkan 36,2\% affect dan didominasi oleh affect of in/security. Selain itu, jenis appraising items yang terjadi dalam affect berita kriminal adalah mental process, behavioural process, relational process, attitudinal lexis, minor clause, epithet and grammatical item.
\end{abstract}

Kata kunci: Appraisal system; Affect; Berita Kriminal

\section{INTRODUCTION}

As social creatures, we can interact with each other so the use of language is very important to communicate. According to Halliday, "Language is a system 
of meaning". It means that people use the language and show the meaning in its language. When people communicate, sometimes they use some tools to deliver their information. It uses mass media such as radio, television, newspaper, book, magazine, etc. Besides, we can also use digital media to communicate such as internet and mobile mass communication.

Nowadays, many people are looking for the information and reading the news using mobile mass communication. They can access it easily through the digital media. So, they can immediately get the news in their grasp. One of the English language newspapers that can be accessed through the digital media is The Jakarta Post and The Jakarta Globe. The Jakarta Post and The Jakarta Globe are the popular digital media and they provide various news for instance Economy, Politic, Crime, etc. This research will analyse the crime news. Referring to The Merriam-Webster Dictionary (2012), "Crime is an act or the commission of an act that is forbidden or the omission of a duty that is commanded by a public law and that makes the offender liable to punishment by that law". News is the new information or a report about something that has happened recently. So, crime news is the news which relates to the act of doing against the law such as murder, rape and theft.

This paper explores Appraisal theory. Appraisal is a language evaluation which analyse the relationship between the speakers and the listeners or the writers and the readers. "Appraisal is concerned with interpersonal language, with the subjective presence of writers/speakers in texts as they adopt stances towards both the material they present and those with whom they communicate. It is concerned with how writers/speakers approve and disapprove, enthuse and abhor, applaud and criticise, and with how they position their readers/listeners to do likewise. It is concerned with the construction by texts of communities of shared feelings and values, and with the linguistics mechanisms for the sharing of emotions, tastes and normative assessments. It is concerned with how writers/speakers construe for themselves particular authorial identities or personae, with how they align or disalign themselves with actual or potential respondents, and with how they construct for their texts an intended or ideal audience. Appraisal involves with the negotiation of social relationship by telling the listeners or readers how they feel about things and people." (Martin \& White, 2005:1).

Appraisal has three kinds of domains: Attitude, Engagement and Graduation. "Attitude is concerned with our feelings, including emotional reactions, judgements of behaviour and evaluation of things. Engagement deals with sourcing attitude and the play of voices around the opinion in discourse. Graduation attends to grading phenomena whereby feelings are amplified and categories blurred." (Martin \& White, 2005:35). Within attitude, Affect shows emotion and feelings. As Martin and White (2005) mentioned, affect expresses feeling and it can be positive or negative, direct or implied. The presence of some lexicogrammatical patterns gives representation to what people feel. Halliday in Martin and Rose (2003:58) distincts affect into three areas: affect as quality, process and comments. It can be seen in the column below: 
Analisis Affect pada Berita Kriminal di The Jakarta Post dan The Jakarta Globe: ...

Table 2.1 Realization of Affect

\begin{tabular}{l|l|l|l}
\hline \multirow{2}{*}{$\begin{array}{l}\text { Affect as } \\
\text { quality }\end{array}$} & $\begin{array}{l}\text { Describing } \\
\text { participants }\end{array}$ & A beautiful relationships & Epithet \\
\cline { 2 - 4 } & $\begin{array}{l}\text { Attributed to } \\
\text { participants }\end{array}$ & $\begin{array}{l}\text { the relationship is } \\
\text { beautiful }\end{array}$ & Attribute \\
\cline { 2 - 4 } & $\begin{array}{l}\text { Manner of } \\
\text { processes }\end{array}$ & $\begin{array}{l}\text { The relationship goes } \\
\text { beautifully }\end{array}$ & Circumstance \\
\hline $\begin{array}{l}\text { Affect as } \\
\text { process }\end{array}$ & Affective sensing & $\begin{array}{l}\text { The speech amazes the } \\
\text { audineces }\end{array}$ & $\begin{array}{l}\text { Process } \\
\text { (effective) }\end{array}$ \\
\cline { 2 - 4 } & Affective behaving & $\begin{array}{l}\text { The audience clap their } \\
\text { hands }\end{array}$ & $\begin{array}{l}\text { Process } \\
\text { (middle) }\end{array}$ \\
\hline $\begin{array}{l}\text { Affect as } \\
\text { comment }\end{array}$ & $\begin{array}{l}\text { Desiderative } \\
\text { comment }\end{array}$ & $\begin{array}{l}\text { Happily, he had a long } \\
\text { nap }\end{array}$ & Modal adjunct \\
\hline
\end{tabular}

By using the appraisal system theory, the research can investigate the writers' feeling or emotion about the crime news in The Jakarta Post and The Jakarta Globe. The research questions of this study are: (1) What are the affect of The Jakarta Post compare to the affect of The Jakarta Globe?; (2) What are type of appraising items in the affect of crime news in The Jakarta Post and The Jakarta Globe?. The objectives of this study: (1) To figure out the affect of The Jakarta Post and the affect of The Jakarta Globe; (2) To describe type of appraising items in the affect of crime news in The Jakarta Post and The Jakarta Globe.

\section{METHODS}

This research conducts the mixed methods in the research. The research will use the quantitative methods and the qualitative methods. The research applies the quantitative methods first, then this research continues with the qualitative methods. The study is descriptive qualitative in nature which the writer only explains and describes the phenomena which exist in the data by employing the theory of Appraisal System.

The data were collected by browsing through internet. The crime news text was, then segmented into sentences or words or phrases as the units of analysis. After that, the writer identified the sentences or words or phrases which display the phenomena of Appraisal System. Finally, the present writer classified the sentences or words or phrases according to the Appraisal System as proposed by Martin and White (2005) before which the categorized Appraisal were tabulated and interpreted.

\section{RESULT AND DISCUSSION}

The research discovered the differences of the affect which occur in The Jakarta Post and The Jakarta Globe as follow 
Table 4.1 The Differences of Affect

\begin{tabular}{c|c|c|c|c|c|c}
\hline \multirow{2}{*}{ Text } & \multicolumn{3}{|c|}{ The Jakarta Post } & \multicolumn{3}{c}{ The Jakarta Globe } \\
\cline { 2 - 7 } & Un/hap & In/sec & Dis/sat & Un/hap & In/sec & Dis/sat \\
\hline 1 & - & - & - & 1 & 2 & - \\
\hline 2 & - & 1 & - & - & 3 & 3 \\
\hline 3 & - & - & - & - & 6 & 1 \\
\hline 4 & - & - & - & - & 3 & 1 \\
\hline 5 & 1 & 2 & 2 & - & - & 2 \\
\hline 6 & 3 & 2 & 6 & 3 & 4 & 1 \\
\hline \multirow{3}{*}{ Total } & 4 & 5 & 8 & 4 & 18 & 8 \\
\cline { 2 - 7 } & \multicolumn{3}{|c|}{$36,2 \%$} & & \multicolumn{3}{c}{$63,8 \%$} \\
\hline Percentage & \multicolumn{3}{|c|}{17} & & & 30 \\
\hline
\end{tabular}

From the result above, it can be seen that the numbers of the expressing affect in The Jakarta Globe are bigger than in The Jakarta Post. The Jakarta Post shows $36,2 \%$ of affect, while The Jakarta Globe shows $63,8 \%$ of affect. This means that the writers in The Jakarta Globe tend to express the feelings mostly in reporting the crime news texts. The writers in The Jakarta Globe also involve the emotion in the crime news text dominantly. In The Jakarta Post, the affects are dominated by the affect of dis/satisfaction (8 items). However, the writers in The Jakarta Globe show the affects in the feeling of in/security (18 items).

\section{Affect of un/happiness}

The results of affect of un/happiness in The Jakarta Post and The Jakarta Globe are only found in the first texts and the sixth texts. This means that the writers express the feeling of un/happiness in the first texts and the sixth texts. And, the present writer found the types of appraising items are in mental process, attitudinal lexis, minor clause and behavioural process.

\section{a. Mental Process}

The research discovered that the affect of un/happiness through mental process only in the first texts. Only The Jakarta Globe shows the affect of un/happiness through mental process in the first text. Here is the example:

(1) "If you don't like this, then you can leave the room, or I will ask security officers to expel you".

The example (1) shows that the underlined example above belongs to the negative affect: unhappiness. It is include in the affect because it describes the emotion and the feeling and it expresses the emotional state of happiness. Otherwise, the words don't like present the negative feeling so that the data (1) belongs to the unhappiness affect. The verb 'like' is the verb of feeling. Thus, the type of the appraising item is mental process. The writer shows the negative feeling through the result of the panel of judges' meeting. 


\section{b. Attitudinal Lexis}

The present writer found that The Jakarta Post and The Jakarta Globe present the affect of un/happiness through attitudinal lexis only in the sixth texts. We can see the data as follow:

(2) Lasmaria and her husband, Toni Manurung, 26, expressed their gratitude.

The phrase 'gratitude' belongs to the positive affect: happiness because it expresses the feeling. Thus, it is include in the affect. Also, the phrase 'gratitude' shows the positive feeling which is felt by Lasmaria and her husband so that it presents the affect of happiness. The form of the data (2) is attribute because the phrase 'gratitude' is attributed to 'Lasmaria and her husband' as the participant. The type of the appraising item is include in the attitudinal lexis because the phrase describes the attitude.

\section{c. Minor Clause}

The present writer discovered that only The Jakarta Globe presents the affect of un/happiness through minor clause and it is found only in the sixth text.

(3) "Alhamdulillah [Praise to God], the baby and the perpetrator have been found," Bandung Police chief Insp. Gen. M. Iriawan said on Friday.

The underlined phrase 'Alhamdulillah' is include in the positive affect: happiness. It is put in the affect because the phrase 'Alhamdulillah' expresses the feeling which is shown by Iriawan. It also describes the positive feeling so that it is called the affect of happiness. The type of appraising item is minor clause. The reason is because the phrase 'Alhamdulillah' contains no predicate. It is mentioned by Iriawan.

\section{d. Behavioural Process}

The present writer discovered that only The Jakarta Post presents the affect of un/happiness through behavioural process and it is found only in the sixth text.

(4) Lasmaria Boru Manulang, 26, broke down in tears.

The underlined data above presents the negative affect: unhappiness. It is called the affect because the participant 'Lasmaria' expresses her feeling. The feeling of the participant 'broke down in tears' shows in the negative so that it is include in the negative affect which is unhappiness affect. The underlined data 'broke down in tears' describes the verb of behaving. Thus, the type of the appraising item is behavioural process. 


\section{Affect of in/security}

The results of affect of in/security in The Jakarta Post are discovered in the second text, the fifth text and the sixth text. Meanwhile, the results of the affect of in/security in The Jakarta Globe are discovered in the first text, the second text, the third text, the fourth text and the sixth text. Also, the types of appraising items in The Jakarta Post and in The Jakarta Globe are epithet, mental process, attitudinal lexis, grammatical item and relational process.

\section{a. Epithet}

The researcher found that only The Jakarta Post presents the affect of security through epithet and it is found only in the second text.

(5) The boy, identified only as AD was arrested at his parents' home in Depok, West java, at 2:30 a.m. on Thursday with the consent of his parents, Rikwanto said.

From the data above, the researcher found that the underlined word 'the consent of his parents' belongs to the positive affect: security. It expresses the feeling of security from the parents so that it presents the affect. It also shows the positive feeling from the parents. Thus, it is called the security affect. The phrase the consent' as an attitude describes the word 'his parents' as the participant. Therefore, the type of this appraising item is epithet.

\section{b. Mental Process}

The research discovered that The Jakarta Post and The Jakarta Globe present the affect of in/security through mental process in the second texts, the third until the sixth texts. However, the results are different. The Jakarta Post presents the affect of in/security through mental process only in the fifth text. While, The Jakarta Globe presents the affect of in/security through mental process in the first text, the second text, the third texts, the fourth text and the sixth text.

In the second texts, the present writer discovered that the affect of in/security through mental process only appears in The Jakarta Globe. There are 1 item of security and 1 item of insecurity in The Jakarta Globe. Here is the example:

(6) He heard noises coming from the house at about 1:30 a.m but didn't think there was a serious problem.

The underlined phrase in the data (6) presents the negative affect: insecurity. It is include in the affect because it shows the feeling of the victim. Also, it is in the negative feeling of insecurity because the victim feels insecure when he heard the noises. The phrase 'think' is the verb of thinking, thus the type of the appraising item is mental process.

In the third texts, the researcher found that only The Jakarta Globe shows the affect of insecurity. It means that The Jakarta Post does not show the feeling of in/security in the third text. The Jakarta Globe only shows the affect of insecurity ( 2 items). This is the example below: 
(7) The suspect was wearing black and is thought to be in his late teens.

The underlined data (7) above indicates the negative affect: insecurity. It is include in the affect because the word 'thought' shows the feeling. Also, it describes the feeling of insecurity because the suspect feels insecure when people know about his age. The type of appraising item is mental process since it uses the verb of thinking. The phrase 'thought' shows the mental verb where it relates to the issue.

In the fifth text, the researcher discovered that The Jakarta Post presents the affect of insecurity through mental process. While, The Jakarta Globe does not present the affect of in/security in the fifth text. The Jakarta Post only shows 1 item of insecurity in the fifth text. Here is the example below:

(8) neither was the woman whom they had thought was a doctor.

From the example above, the underlined phrase in the data (8) shows the negative affect: insecurity. The phrase 'thought' expresses the feeling of the participant in the data. Thus, it is put in the affect. It also describes the negative feeling because 'they' thought 'the woman' is the doctor but the fact is not. Thus, it is put in the insecure feeling. The type of appraising item is mental process because it uses the verb of thinking 'thought'. It explains the insecure feeling of the baby's parents using the mental verb.

In the sixth text, The Jakarta Post does not express the affect of in/security. However, The Jakarta Globe expresses the affect of in/security. There are 1 item of security in The Jakarta Globe. The following example from The Jakarta Globe can be seen as follow:

(9) they thought was a doctor at Hasan Sadikin's maternity ward.

From the example above, the underlined phrase in the data (9) shows the negative affect: insecurity. The phrase 'thought' shows the feeling of the participant in the data. Thus, it is put in the affect. It also describes the negative feeling because 'they' thought 'the woman' is the doctor but the fact is not. Thus, it is put in the insecure feeling. The type of appraising item is mental process because it uses the verb of thinking 'thought'. It explains the insecure feeling of the baby's parents using the mental verb.

\section{c. Attitudinal Lexis}

The research found that The Jakarta Post and The Jakarta Globe show the affect of in/security through attitudinal lexis in the first text, the fourth text and the sixth texts. The Jakarta Post shows the affect of in/security through attitudinal lexis only in the sixth text. But, The Jakarta Globe shows the affect of in/security through attitudinal lexis in the first text, the fourth text and the sixth text. 
In the first texts, the research found out that The Jakarta Globe presents the affect of insecurity through attitudinal lexis. However, The Jakarta Post does not present the affect of in/security through attitudinal lexis in the first text. There is only 1 item of insecurity in The Jakarta Globe. we can see the example as follow:

(10) John was found guilty of the brutal murder of 51-year-old Sanex Steel president director Tan Harry Tantono on Jan, 26.

From the data (10) above, the underlined phrase 'guilty' belongs to the negative affect: insecurity. It includes in the affect because the phrase 'guilty' expresses the feeling and it is shown the negative feeling. Thus, the phrase 'guilty' describes the insecure feeling. The type of appraising item is attitudinal lexis because the phrase 'guilty' describes the attitude and it relates to the feeling.

In the fourth text, the research did not discover the affect of in/security through attitudinal lexis in The Jakarta Post. While, it is found the affect of insecurity through attitudinal lexis in The Jakarta Globe. There are 2 items of insecurity in the fourth text of The Jakarta Globe. Here is the example:

(11) "The victim is traumatized and still in shock" Khoiri said.

As figured in the example above, the underlined phrases 'traumatized' and 'in shock' show the negative affect: insecurity. Those phrases relate to the emotions which are shown by the victim. Thus, it is put in the affect. Those phrases also show the negative feelings when the victim feels insecure to the situation. The phrases 'traumatized' and 'in shock' in the data (11) are include in attitudinal lexis as the type of appraising items. They describe the attitude and show the feeling.

In the sixth text, The Jakarta Post and The Jakarta Globe express the affect of in/security through attitudinal lexis in the sixth texts. The Jakarta Post shows 1 item of security and 1 item of insecurity. While, The Jakarta Globe shows only 1 item of security.

(12) After the police found their daughter safe and sound and caught the perpetrator on Friday evening.

The underlined phrase in the data (12) belongs to the positive affect: security. It is put in the affect because it shows the feeling of the baby's parents who feel secure to their baby. The phrase 'safe' also shows the positive feeling. Thus, it is called the security feeling. The type of appraising items is attitudinal lexis. The reason is because the phrase 'safe' is the lexis which describes the attitude.

\section{d. Grammatical Item}

The research discovered that the affect of in/security through grammatical item can be seen in the second texts and the third texts. But, only The Jakarta 
Globe shows the affect of in/security through grammatical item. The affect of in/ security through grammatical item is not found in The Jakarta Post.

In the second text, we can find out that The Jakarta Post does not express the affect of in/security through grammatical item in the second text. However, The Jakarta Globe expresses the affect of insecurity through grammatical item in the second text. In The Jakarta Globe, there is only 1 tem of insecurity. The following is the example from The Jakarta Globe:

(13) The suspect is alleged to have killed Jordan Raturamon and his son, Edward Rturamon, 22, on Wednesday.

From the example above, the underlined phrase 'alleged' is the negative affect: insecurity. The appraised item in the data (13) is the suspect who expresses the feeling so that it is put in the affect. It also shows the negative feeling because the suspect is claimed to kill Jordan Raturamin and his son. The suspect feels insecure to the issue, thus it is called the affect of insecurity. The word 'alleged' is the item which carries specific lexical meaning in the data so that it is called grammatical item as the type of appraising item. The writer uses the phrase 'alleged' to describe the issue in the data.

In the third text, it is discovered that only The Jakarta Globe presents the affect of in/security through grammatical item. The Jakarta Post does not present the affect of in/security through grammatical item. In The Jakarta Globe, there are 2 items of insecurity. This is the example:

(14) Female journalist sexually assaulted in East Jakarta.

The underlined phrase 'sexually' in the data (14) above shows the negative affect: insecurity. It is put in the affect because it describes the feeling of the journalist who feels insecure when she is assaulted and it is put as the circumstance in the data. The phrase 'sexually' belongs to the negative feeling, thus it is the insecurity. The phrase 'sexually' belongs to the grammatical item as the type of appraising item because this word describes the lexical meaning in the data.

\section{e. Relational Process}

The research discovered that the affect of in/security through relational process is in the third text. Only The Jakarta Globe shows the affect of in/security through relational process.

In the third text, The Jakarta Globe presents 1 item of insecurity through relational process. Here is the example below:

(15) the suspect did not appear to be under the influence of alcohol or drugs.

From the data (15) above, the underlined data belongs to the negative affect: insecurity. It is put in the affect because it relates to the feeling which refers to the suspect. The suspect is mentioned that he is not influenced by the alcohol or 
drugs. Thus, the underlined data is the negative feeling and it is called the insecurity. The data (15) shows that the data is the attributive of the relational process because the carrier has an attribute (under the influence of alcohol or drugs). Thus, the type of appraising item is relational process.

\section{Affect of dis/satisfaction}

The results of affect of dis/satisfaction in The Jakarta Post are discovered in the second texts, the third texts, the fifth texts and the sixth texts. The Jakarta Post shows the affect of dis/satisfaction in the fifth text and the sixth text. Meanwhile, the results of the affect of dis/satisfaction in The Jakarta Globe are discovered in the second text, the third text, the fourth text and the sixth text. Also, the types of appraising items in The Jakarta Post and in The Jakarta Globe are epithet, mental process, attitudinal lexis, grammatical item and relational process.

\section{a. Mental Process}

The research discovered that the affect of dis/satisfaction through mental process is in the second texts, the fourth text, the fifth texts and the sixth texts. The Jakarta Post shows the affect of dis/satisfaction through mental process in the fifth text and the sixth text. Meanwhile, The Jakarta Globe shows the affect of dis/satisfaction through mental process in the second text, the fourth text, the fifth text and the sixth text.

In the second text, The Jakarta Globe shows 3 items of satisfaction through mental process. The Jakarta Post does not show the affect of dis/satisfaction through mental process in the second text. This is the example from The Jakarta Globe:

(16) According to the police, the two suspects knew the victims.

From the example above, we can see the underlined phrase ' $\mathrm{knew}^{\prime}$ belongs to the positive affect: security. It is include in the affect because the phrase ' $\mathrm{knew}^{\prime}$ describes the feeling of the participants, the two suspects. That phrase also describes the positive feeling and it shows the pursuit of goal because the two suspects can know the victims. Thus, it is put in the satisfied affect. The type of appraising item is mental process because from the data (16), it is found the verb of thinking 'know'.

In the fourth text, The Jakarta Globe presents 1 item of satisfaction through mental process. The Jakarta Post does not present the affect of dis/satisfaction through mental process in the fourth text. The following is the example from The Jakarta Globe:

(17) she already knew one of the assailants

The underlined phrase ' $k$ new' above shows the positive affect: satisfaction. It is include in the affect because the verb 'knew' describes the feeling through the process. It is the positive feeling of satisfaction because we can see the writer shows their feeling through the pursuing goals. The type of appraising item is 
mental process. The data displays that the verb 'knew' is one of the thinking verbs in the mental process.

In the fifth text, the researcher found out that The Jakarta Post and The Jakarta Globe display the affect of dis/satisfaction through mental process. The Jakarta Post presents the 2 items of positive feeling of affect. While, The Jakarta Globe presents 1 item of positive feeling of affect and 1 item of negative feeling of affect. Here is one of the example from The Jakarta Post:

(18) Lasmaria and Toni realized their baby had been kidnapped

The underlined phrase 'realized' in the data above shows the positive affect: satisfaction. It describes the feeling of Lasmaria and Toni so that it is include in the affect. The phrase 'realized' also shows the positive feeling of Lasmaria and Toni who know their baby was kidnapped. Thus, it is put in the affect of satisfaction. The type of appraising item is mental process because the data (18) shows that the verb 'realized' is one of the thinking verbs in the mental process.

In the sixth text, The Jakarta Post and The Jakarta Globe present the affect of satisfaction through mental process, but both of them do not present the affect of dissatisfaction through mental process. The Jakarta Post presents 4 items of the affect of satisfaction through mental process. The Jakarta Globe also presents 1 item of satisfaction through mental process in the sixth text. Here is the example from The Jakarta Post:

(19) I just want thank the police officers who had worked tirelessly on this case

The data (19) above presents the positive affect: satisfaction. It belongs to the affect because the phrase 'want' describes the emotion through the process. Beside that, the phrase 'want' shows the positive feeling and they show the satisfaction of the participant in the data. Thus, it is the affect of satisfaction. The verb 'want' is the verb of wanting in the mental process so that it is include in the mental process as the type of appraising item.

\section{b. Relational Process}

The research discovered that the affect of dis/satisfaction through relational process is only in the sixth text. Only The Jakarta Post shows the affect of dis/satisfaction through relational process in the sixth text.

In the sixth text, the research discovered that The Jakarta Post presents 1 item of satifaction through relational process. But, The Jakarta Globe does not present the affect of dis/satisfaction through relational process. We can see the example from The Jakarta Post below:

(20) she was healthy

According to the data above, the underlined phrase 'healthy' is the positive affect: satisfaction. It shows the affect because the participant shows the feeling through 
attribute. The phrase 'healthy' explains the positive feeling and it gives the satisfaction to the participant when she is healthy. Therefore, it is called the affect of satisfaction. The data (20) shows that the data is the attributive of the relational process because the carrier has an attribute (healthy). Thus, the type of appraising item is relational process.

\section{c. Attitudinal Lexis}

The research discovered that the affect of dis/satisfaction through attitudinal lexis is only in the third text. Only The Jakarta Globe shows the affect of dis/satisfaction through relational process in the third text.

In the third text, The Jakarta Globe presents 1 item of dissatisfaction through attitudinal lexis. But, The Jakarta Post does not present the affect of dis/satisfaction through attitudinal lexis in the third text. This is the example from The Jakarta Globe:

(21) She is still in shock

From the data (21), the underlined phrase 'in shock' belongs to the negative affect: dissatisfaction. It shows the affect because it describes the feeling of the participant in the data. Moreover, the phrase 'in shock' is the negative feeling because she still feels in shock. Thus, it is include in the affect of dissatisfaction. The type of appraising item is attitudinal lexis because the data (21) uses the phrase 'in shock' which describes the attitude. Therefore, it is called the attitudinal lexis.

\section{d. Grammattical Item}

The research discovered that the affect of dis/satisfaction through grammatical item is in the sixth text. Only The Jakarta Post shows the affect of dis/satisfaction through grammatical item in the sixth text.

In the sixth text, The Jakarta Post presents 1 item of dissatisfaction through grammatical item. While, The Jakarta Globe does not present the affect of dis/satisfaction through grammatical item in the sixth text. Here is the example from The Jakarta Post:

(22) I just want thank the police officers who had worked tirelessly on this case

The data (22) above shows the negative affect: dissatisfaction. It indicates the affect because it describes the affect through circumstance. Beside that, the word 'tirelessly' show the negative feeling and it shows the feeling of dissatisfaction. Thus, it is called the affect of dissatisfaction.

The type of appraising item is grammatical item because the word 'tirelessly' is the item which carries specific lexical meaning in the data. So, it is called grammatical item.

\section{CONCLUSIONS}

Based on the results of expressing affect in The Jakarta Post and The Jakarta Globe from the first texts to the sixth texts, there are $36,2 \%$ of affect in The Jakarta 
Post which contain the affect of un/happines (4 items), the affect of in/security (5 items) and the affect of dis/satisfaction (8 items); and there are $63,8 \%$ of affect in The Jakarta Globe which contain the affect of un/happiness (4 items), the affect of in/security (18 items) and the affect of dis/satisfaction ( 8 items). The numbers of affect in The Jakarta Globe are bigger than the numbers of the affect in The Jakarta Post. This means that the writers of The Jakarta Globe tend to express the feeling dominantly in reporting the crime news texts. In addition, the research also discovered that the types of appraising items in the affect of crime news are mental process, behavioural process, relational process, attitudinal lexis, minor clause, epithet and grammatical item. It is also suggested to other researchers especially who want to do research about appraisal to relate it to the other approaches such as Pragmatics, Critical Discourse Analysis, Applied Linguistics, etc.

\section{REFERENCES}

Creswell, John. W. (2003). Research Design: Qualitative, Quantitative and Mixed Methods Approaches. Second Edition: Sage Publications, Inc.

Derewianka, Beverly. (2011). A New Grammar Companion for Teachers. Second Edition: Primary English Teaching Association.

Deterding, David and Poedjosoedarmo, Gloria. R. (2001). The Grammar of English, Morphology and Syntax for English Teachers in Southeast Asia. Singapore: Prentice Hall.

Eggins, Suzanne. (1994). An Introduction to Systemic Functional Linguistics. London: Pinter Publishers.

Kusumawardhani, Ratna. (2007). Interpersonal Meaning in English and Javanese Catholic Daily Prayers. Graduate These. Semarang: Semarang State University. [09/26/14]

Halliday, M. A. K and Matthiessen, Christian, M.I.M. (2004). An Introduction to Functional Grammar. Third Edition, London: Edward Arnold.

Hood, Susan. (2010). Appraising Research: Evaluation in Academic Writing. First Edition, Palgrave Macmillan.

Martin, J. R and Rose, David. (2007). Working with Discourse - Meaning beyond the Clause. Second Edition: The British Library.

Martin, J. R and White, P.R.R. (2005). The Language of Evaluation - Appraisal in English. First Edition, Palgrave Macmillan.

Martin, J. R. (2000). Beyond Exchange: Appraisal Systems in English. in Huston, S \& Thomson, G. (eds), Evaluation in Text, Oxford: Oxford University Press.

Sugiyono. (2013). Metode Penelitian Kuantitatif Kualitatif dan RED. Bandung: Alfabeta.

Sujatna, Eva Tuckyta Sari. (2013). Understanding Systematic Functional Linguistics. Bandung: Unpad Press. 
Warsono. 2006. Appraisal System Used in Ruth Suckow's Short Story "A Start Life": Attitude and Feelings. Graduate These. Semarang: Semarang State University. [12/18/14]

Widhiyanto. 2004. Appraisal System Used to Express Ideologies in The Jakarta Post Issue: Gus Dur versus KPU. Graduate These. Semarang: Semarang State University. [11/10/14]

Widya, Valentina. 2008. Analisis Sistem Appraisal dan Ideologi dalam Kolom Punk-Zine. Semarang: Diponegoro University. [03/05/14]

White, P. R. (1998). Telling Media Tales: the news story as rhetoric. Sydney: University of Sydney. 